\title{
Naudanlihantuotannon optimointi tukipolitiikan muutoksessa
}

\author{
Pekka Pihamaa $^{1)}$ ja Kyösti Pietola ${ }^{2)}$ \\ ${ }^{1)}$ MTT Taloustutkimus, PL 3, 00411 Helsinki, pekka.pihamaa@mtt.fi \\ ${ }^{2)}$ MTT Taloustutkimus, PL 3, 00411 Helsinki, kyosti.pietola@ mtt.fi
}

\section{Johdanto}

Suomalaisen naudanlihan tarjonta on viime vuosina heikentynyt. Naudanlihaa tuotettiin vuonna 1991 noin 122 miljoonaa kiloa, kun vuonna 2000 tuotanto oli laskenut 91 miljoonaan kiloon. Vuonna 2000 kotimainen tuotanto kattoi enää 94 prosenttia kotimaisesta kulutuksesta siitäkin huolimatta, että myös naudanlihan kysyntä on ollut laskusuunnassa (MTTL 2001, s. 35). Naudanlihan tuottajahintojen voimakkaasti alentuessa suomalaisen naudanlihan tarjontaa on ylläpidetty kansallisin tukitoimenpitein. Kansallisen tuen merkitys Suomen naudanlihasektorilla korostunee jatkossa aikaisempaa voimakkaammin, koska EU:n yhteisen Agenda 2000 uudistuksen eräänä tavoitteena oli heikentää naudanlihan tarjontaa etenkin Euroopan voimaperäisimmillä kotieläinalueilla. (Peltomäki 2000, s. 1).

Lihanaudankasvatuksessa ruokinta vaikuttaa kasvunopeuteen, joka taas yhdistää teuraspainon ja teurastusajankohdan toisiinsa. Näin ollen teurastusajankohtaa ja ruokintaa ei voida ratkaista toisistaan erillään. Sama elopainon lisäys voidaan aikaansaada hyvin monenlaisella ruokinnalla, ellei painon lisäykseen kuluvaa aikaa oteta huomioon tarkastelussa. Toisaalta saman suuruinen päiväkasvukin voidaan saavuttaa usealla rehuyhdistelmällä.

Tämän tutkimuksen tavoitteena on rakentaa optimointimalli, joka määrittää lihanaudan optimaalisen ruokinnan ja teurastuksen ajoituksen. Optimointimalli perustuu dynaamisen ohjelmoinnin ideaan. Tavoitteena on maksimoida naudanlihan tuotannosta saatava ylijäämä joka saadaan, kun eläinpaikalle saaduista lihanmyyntituotoista ja eläintuista vähennetään ruokinta- ja vasikkakustannukset. Tavoitteena on selvittää, kuinka lihanaudan kasvatuksen ylijäämä, optimaalinen ruokinta ja teurastuksen ajoitus muuttuvat Agendan 2000:n vaikutuksesta. Tutkimuksessa optimoidaan maitorotuisen sonnin ruokinta ja teurastuksen ajoitus sekä vuosien 1998 ja 2002 hinnoin. Tutkimuskohteena on C2-tukialue, koska alueella tuotetaan noin 40 prosenttia suomalaisesta naudanlihasta (TIKE 2000).

Dynaamista ohjelmointia on maataloudessa sovellettu muihinkin kuin lihanaudan kasvatuksen ja tuotantopanosten käytön taloudellisiin optimointiongelmiin. Kotieläintuotannossa dynaamista ohjelmointia on käytetty mm. optimoitaessa 1) lypsylehmien tuotantokausien määrää, 2) laiduntavien nautojen määrää laitumen koon ollessa annettu sekä 3) lihantuotantoeläinten ruokintaa ja teurastuksen ajankohtaa. Kasvinviljelyssä dynaamista ohjelmointia on käytetty mm. optimoitaessa 1) kasteluveden jakoa, 2) hyönteistorjuntaa ja 3) fosforilannoitusta. Dynaamista ohjelmointia on käytetty myös maatalouskoneiden optimaalisen vaihtovälin määrittelyyn (Kennedy 1986).

\section{Menetelmä}

Naudanlihan kasvatuksen optimointiongelma kirjoitetaan Bellmannin yhtälön avulla seuraavassa muodossa:

$$
\text { (1) } V_{t}\left(x_{t}\right)=\max _{u^{s}, u^{f}}\left\{R_{t}\left(x_{t}, u_{t}^{s}, u_{t}^{f}\right)+\beta V_{t+1}\left(x_{t+1}\right)\right\}
$$

missä $V_{t}\left(x_{t}\right)$ on arvofunktio (value function), $R_{t}($.$) on yhden periodin tuottofunktio ja V_{t+1}\left(x_{t+1}\right)$ on seuraavan periodin arvofunktio. Lihanaudan kasvatuksessa tilannemuuttujana on eläimen paino $\left(x_{t}\right)$. Kaikille tilannemuuttujien arvoille lasketaan, teurastetaanko eläin vaiko kasvatetaanko sitä edelleen ja millaisella ruokinnalla. Diskonttaustekijä $\beta$ on määritelty sovittamalla käytettävä vuotuinen korko tarkasteluperiodin $(t)$ pituuteen.

Ohjausmuuttuja $\left(u_{t}^{s}\right)$ säätelee, jatketaanko eläimen kasvatusta vai teurastetaanko se. Ohjausmuuttuja $\left(u_{t}^{s}\right)$ voi siis saada arvon nolla tai yksi. Toinen ohjausmuuttuja $\left(u_{t}^{f}\right)$ on ruokinnan 
voimakkuus, joka vaikuttaa kasvunopeuteen ja rehunkulutukseen. Ruokinnan voimakkuus voidaan valita kahdesta väkirehutasosta. Jokaiseen tilannemuuttujan ja ohjausmuuttujan arvoon on liitetty oma rehun kysyntä. Ajan kulumista seuraa indeksimuuttuja $t$ ja optimointiperiodin pituus on $T$.

Jos eläintä päätetään edelleen kasvattaa, $u_{t}^{s}=0$ ja siirtymäfunktio eläimen painolle $x_{t}$ on

$$
\text { (2) } x_{t+1}=x_{t}+f_{t}\left(x_{t}, u_{t}^{f}\right) \text {, }
$$

jossa $f_{t}\left(x_{t}, u_{t}^{f}\right)$ on eläimen kasvu hetkien $t$ ja $t+1$ välillä. Kasvu riippuu eläimen elopainosta ja ruokinnasta ekonometrisesti estimoitujen kasvunopeusyhtälöiden mukaisesti.

Jos eläin teurastetaan, $u_{t}^{s}=1$ ja siirtymäfunktio on

$$
\text { (3) } x_{t+1}=x_{0} \text {, }
$$

jossa naudanlihatilalle välityksestä saapuvan vasikan paino on $x_{0}$.

Yhden periodin tuottofunktio voidaan kirjoittaa:

$$
R\left(x_{t}, u_{t}^{s}, u_{t}^{f}\right)=\left(1-u_{t}^{s}\right) *\left[-C\left(u_{t}, x_{t}^{f}\right)+S^{C A P}\left(x_{t}\right)+S^{N A T}\left(x_{t}\right)\right]+u_{t}^{s}\left[L p_{m} x_{t}+S_{s}-p_{c}\right]
$$

jossa rehun kysyntäfunktiosta on johdettu ruokintakustannus $\left(C\left(u_{t}^{f}, x_{t}\right)\right)$. Lihanaudoille kasvuperiodin aikana maksettava EU-sonnipalkkio on $S^{C A P}$ ja eläimelle kasvuperiodin aikana kertyvä kansallinen tuki on $S^{N A T}$. Teurasprosentti on $L$ ja lihan hinta on $p_{m}$. Teurastuksen yhteydessä maksettava tuki on $S_{s}$ ja vasikan hinta on $p_{c}$.

Yhden periodin tuottofunktio on positiivinen, kun eläin teurastetaan ja kun eläin saa CAP -tuen. Muina periodeina yhden periodin tuottofunktio on negatiivinen ja yhtä suuri kuin ruokintakustannus, josta on vähennetty eläimen mahdollisesti saama kansallinen tai pohjoinen tuki.

Viimeisellä periodilla $(t=T)$ eläin aina teurastetaan ja tämän periodin tuotto on sama kuin eläimen teurasarvo (Pietola 1999):

$$
R_{T}=L p_{m} x_{T}+S_{s}
$$

\section{Aineisto}

Tutkimusaineistona käytetään MTT:ssa vuosina 1995-1996 Jokioisten Lintupajun mullikoenavetassa tehtyä Ayrshire-sonnien kasvatuskoetta (mm. Rinne ym. 1998, s. 131-136). Optimointimallissa rehunkäyttö ja kasvunopeus on määritelty tämän kokeen kahden eri koeryhmän tulosten perusteella. Ryhmän 1 väkirehuannos oli $100 \mathrm{~g}$ väkirehun kuiva-ainetta per elopaino, ${ }^{0,6}$ ja ryhmän 2 väkirehuannos $50 \mathrm{~g}$ väkirehun kuiva-ainetta per elopaino ${ }^{0,6}$. Koko kasvatuskauden aikana väkirehun osuus dieetin kokonaiskuiva-aineen määrästä oli ryhmällä 1 noin 40 prosenttia ja ryhmällä 2 noin 25 prosenttia. Lisäksi eläimet saavuttivat varsin korkean kasvunopeuden. Ryhmän 1 nettokasvunopeus oli noin 620 g/päivä ja ryhmän 2 noin $570 \mathrm{~g} / \mathrm{päivä.}$

Eläinten kasvu estimoitiin Gompertz-funktiona, jota on yleisesti käytetty eläinten kasvufunktioiden estimointiin. Säilörehun tarpeen määrittelemiseksi estimoitiin säilörehun kulutuksen ja elopainon välille logaritminen funktio. Ohran kulutus optimointimallissa määriteltiin potenssifunktiona.

Raskaasta teuraasta (250-300 kg) maksettuna lihan hintana käytettiin vuoden 1998 osalta 15,30 $\mathrm{mk} / \mathrm{kg}$ ja vuoden 2002 osalta $14,00 \mathrm{mk} / \mathrm{kg}$. Hinta porrastettiin eläinten painon mukaan. Ohran hinta on markkinahinta, johon on lisätty hävikistä ja jauhatuksesta syntyvä kustannus (Taulukko 1). Säilörehusta käytettiin kolmea eri hintaa: korkea, keskimääräinen, ja matala. Korkea hinta kuvaa keskimääräistä tuotantokustannusta, keskimääräinen hinta vastaa säilörehun keskimääräisiä muuttuvia kustannuksia ja matalin hinta taso kuvaa säilörehun edullisimmin tuottavien tilojen säilörehun hintaa. Rypsirouheen ja kivennäisen osalta on käytössä markkinahinta. Vasikan hinta sisältää välityskustannuksen. 
Taulukko 1. Tutkimuksessa käytettyjä hintoja.

\begin{tabular}{lccr}
\hline & yksikkö & 1998 & 2002 \\
\hline Ohra & mk/kgKA & 0,92 & 0,78 \\
Säilörehu & & & \\
$\quad$ Matala & mk/kgKA & 0,66 & 0,70 \\
$\quad$ Keskimääräinen & mk/kgKA & 0,82 & 0,88 \\
$\quad$ Korkea & mk/kgKA & 1,31 & 1,39 \\
Rypsirouhe & mk/kg & 1,94 & 1,94 \\
Kivennäinen & mk/kg & 2,75 & 2,75 \\
Vasikka & $\mathrm{mk}$ & 1448 & 1208 \\
\hline
\end{tabular}

\section{Tulokset}

Vuoden 1998 hinnoin laskettuna optimaalinen teurastushetki määräytyy kansallisen tuen toisen portaan perusteella. Optimaalinen teurasikä on 14-15 kuukautta ja teuraspaino noin 260 kiloa. Säilörehun hinta ei juurikaan vaikuta optimiin, mutta sillä on kuitenkin melko suuri vaikutus arvofunktion arvoon ja dieetin karkea- ja väkirehun suhteeseen.

Taulukko 2. Optimaalinen teurastusajankohta vuoden 1998 hinnoin.

\begin{tabular}{lcrrr}
\hline & & Säilörehun hinta & Säilörehun hinta & Säilörehun hinta \\
$(0,66)$ & yksikkö & 255 & 255 & $(1,31)$ \\
\hline Ruhopaino & $\mathrm{kg}$ & 14,9 & 14,9 & 253 \\
Ikä & kuukausi & 13145 & 11803 & 14,4 \\
Arvofunktion arvo & markkaa & & & 8177 \\
Väki- ja karkearehun suhde & \% kuiva- & & & \\
dieetissä & aineessa* & $24 / 76$ & $24 / 76$ & $35 / 65$ \\
\hline
\end{tabular}

* Väki -ja karkearehun suhde dieetin kokonaiskuiva-aineen määrästä.

Vuoden 2002 hinnoin laskettuna optimaalinen teuraspaino on noin 190 kiloa ja teurasikä noin 11 kuukautta. Tätä kuten edellistäkin tulosta tarkasteltaessa on otettava huomioon, että eläinten tulee varmuudella ylittää määritelty optimi. Näin keskimääräisen teuraspainon tulee olla optimia suurempi. Optimaalinen teurasikä ja -paino määräytyvät vuonna 2002 pääosin CAP -tuen ehtojen perusteella. Arvofunktion arvo kasvaa vuosien 1998 ja 2002 välillä jossain määrin (eli noin 2300 - 3600 markkaa). Tämä tarkoittaa vuodessa sonnipaikkaa kohden noin 370-580 markkaa.

Optimointirutiinia simuloitiin myös muuttamalla lihan ja vasikan hintoja +/- $15 \%$. Tulokset kuitenkin viittaavat siihen, että eläimestä maksettu tuki dominoi optimaalista teurastuksen ajoitusta eikä hintamuutoksilla ollut oleellista vaikutusta optimaaliseen teurastuksen ajoitukseen. Hintamuutoksilla on kuitenkin suuret tulovaikutukset, koska hintojen muuttuessa arvofunktion arvo muuttui oleellisesti.

Taulukko 3. Optimaalinen teurastusajankohta vuoden 2002 odotetuin hinnoin.

\begin{tabular}{lcrrr}
\hline & & Säilörehun hinta Säilörehun hinta Säilörehun hinta \\
& yksikkö & $(0,70)$ & $(0,88)$ & $(1,39)$ \\
\hline Ruhopaino & $\mathrm{kg}$ & 191 & 191 & 194 \\
Ikä & kuukausi & 10,9 & 10,9 & 10,9 \\
Arvofunktion arvo & markkaa & 15475 & 14289 & 11828 \\
Väki- ja karkearehun suhde & \% kuiva- & & & \\
dieetissä & aineessa* & $32 / 68$ & $33 / 67$ & $42 / 58$ \\
\hline
\end{tabular}

* Väki -ja karkearehun suhde dieetin kokonaiskuiva-aineen määrästä. 
Koska tukipolitiikalla on keskeinen vaikutus teurastuksen ajoitukseen, mallia simuloitiin tavoitteena selvittää, kuinka paljon raskaille eläimille tulisi maksaa tukea, jotta optimaalinen teuraspaino nousisi 270 kiloon. Raskaille eläimille maksettavan lisätuen tarve vaihteli 400-800 markan välillä, riippuen säilörehun hinnasta. Säilörehun hinnoitteluperuste vaikuttaa myös melkoisesti ruokinnan optimaaliseen karkea- ja väkirehun suhteeseen.

Taulukko 4. Lisätuen tarve teuraspainon kohottamiseksi.

\begin{tabular}{|c|c|c|c|c|}
\hline & yksikkö & $\begin{array}{c}\text { Säilörehun hinta } \\
(0,70)\end{array}$ & $\begin{array}{c}\text { Säilörehun hinta } \\
(0,88)\end{array}$ & $\begin{array}{c}\text { Säilörehun hinta } \\
(1,39)\end{array}$ \\
\hline Ruhopaino & $\mathrm{kg}$ & 272 & 271 & 271 \\
\hline Ikä & kuukausi & 16.3 & 16.0 & 15.8 \\
\hline Arvofunktion arvo & markkaa & 15687 & 14526 & 11617 \\
\hline Lisätuen tarve & markkaa & 400 & 500 & 800 \\
\hline $\begin{array}{l}\text { Väki- ja karkearehun suhde } \\
\text { dieetissä }\end{array}$ & $\begin{array}{l}\% \text { kuiva- } \\
\text { aineessa* }\end{array}$ & $26 / 74$ & $29 / 71$ & 37 / 67 \\
\hline
\end{tabular}

* Väki -ja karkearehun suhde dieetin kokonaiskuiva-aineen määrästä.

\section{Johtopäätökset}

Tulokset puoltavat näkemystä, että EU:n yhteisen Agenda 2000 -uudistuksen vaikutukset suomalaisen naudanlihan tarjontaan noudattavat uudistuksen yleisiä tavoitteita. Uudistus alentaa optimaalisia teuraspainoja ja heikentää naudanlihan tarjontaa jopa $15 \%$, ellei uudistusta täydennetä kansallisilla politiikkaohjelmilla eikä lihanjalostusteollisuudessa jyrkennetä eläimen painon mukaisia hinnoitteluportaita. Toisaalta Agenda-uudistuksen tulovaikutus on myös näiden tulosten mukaan tuottajille myönteinen.

Mikäli maitorotuisten sonnien optimaaliset teuraspainot halutaan yksin tukipolitiikan keinoin korottaa yli 270 kilon, olisi raskaille naudoille maksettavaa tukea tulosten mukaan korotettava 400800 mk säilörehun hinnasta riippuen. Tulokset puoltavat myös näkemystä, että painaville sonneille maksettava lisätuki on tehoton keino lisätä viljelijän tuloja, koska teuraspainojen korottaminen lisää tuotantokustannuksia

\section{Kirjallisuus}

Kennedy, J. O. S. 1986. Dynamic Programming. Applications to Agriculture and Natural Resources. 331 p. New York.

MTTL 2001. Suomen maatalous ja maaseutuelinkeinot 1998. Maatalouden taloudellinen tutkimuslaitos julkaisuja $97.95 \mathrm{~s}$.

Pietola, K. 1999. Dosentuuriluennon kalvomateriaali. Helsingin yliopisto 1.10.1999.

Rinne, M., Manni, K. \& Huhtanen, P. 1998. Väkirehun ruokintastrategiat lihanaudoilla. Kotieläintieteen päivät 1998. Maaseutukeskusten Liiton julkaisuja 924: 131-136.

TIKE 2000. Maatilatilastollinen vuosikirja. Maa- ja metsätalousministeriön tietopalvelukeskus. Helsinki. 